\title{
Intercropping of Cereals and Legumes for Forage Production
}

\author{
Hamdollah ESKANDARI' ${ }^{1}$, Ahmad GHANBARI ${ }^{2}$, Abdollah JAVANMARD ${ }^{3}$ \\ 1) University of Payame Noor, Department of Agriculture, Omidieh branch, Omidieh, Iran; ehamdollah@gmail.com \\ 2) University of Zabol, Faculty of Agriculture, Department of Agronomy and Plant Breeding, Zabol, Iran \\ 3) Azad University of Mahabad, Faculty Member of Islamic, Mahabad, Iran
}

\begin{abstract}
Cereals are high important in feeding ruminant animals for their high dry matter production and low cost. However, cereals forage is poor in protein content which shows their low quality and nutritive value. Regarding to high feed costs of protein supplementations, legumes can be used in livestock nutrition for their high protein content and, thus, providing cost saving. Since legumes have low dry matter yield, acceptable forage yield and quality can obtained from intercropping of cereals and legumes compared with their sole crops. In this paper, forage quality indicators and different factors affecting forage quality are discussed. Forage production and quality of different cereals-legumes intercropping are also reviewed, where; different legumes had different effect on forage quality when intercropped with specific cereal. Regarding to forage quality and quantity, different cereals also led to different production of forage. A number of factors which must be noticified in selecting cereal-legume intercropping compositions, especially for forage production, were considered.
\end{abstract}

Keywords: barley, crude protein, forage quality, mixed cropping, maize, wheat

\section{Introduction}

Forages are important in the world's food resources as plant materials containing high amounts of structured carbohydrates. Since many monogastrics, including man, are very limited in their capacity to handle these fibrous carbohydrates, their usefulness lies in utilization by ruminant animals (Ghanbari Bonjar, 2000). However, the ruminant is unique in having the potential for cycling forage materials, poor quality protein and non protein nitrogen sources into the human food supply as meat and milk. Thus, management of forage crop production must be more regarded. Livestock nutritional resources are pastures, meal and forage crops. Although concentrates have been used in the dairy cattle rations, forage crops perform an important role in energy and protein supply for livestock.

Cereals are widespread used in livestock nutrition due to their high dry matter production and low cost (GhanbariBonjar, 2000) and a number of cereals grown for forage, for example maize and wheat, have become of increased importance in the rations of ruminants animals (Leaver and Hill, 1992). These types of cereal-based forages have the potential to supply large amount of energy for animals. Unfortunately, cereals often contain low protein and, thus, low forage quality. Since adequate animal nutrition is essential for high rates of gain ample milk production, efficient reproduction and adequate profits, it is necessary to provide livestock with protein supplements when forage quality is low. The purchase of protein supplementation is expensive and results in high feed costs which forcing dairy farmers to become more efficient with their farm operation. Since feed accounts for approximately one-half of the total cost of providing milk, and high quality forage optimizes the productivity of the animals, increasing the quality of forage available is one of the best methods of improving overall feeding efficiency. Combining the growth of cereals forage with crops which are capable of increasing the protein content of the overall ration clearly has nutritional and financial potential. Legumes are good source of protein and can be used to compensate cereal protein shortage (Gebrehiwot et al., 1996). Thus, growing of crop mixtures with legumes, which referred to intercropping, can boost the forage protein content of diets.

Intercropping, which is defined as the growing of two or more crop species simultaneously in the same field during a growing season (Ofori and Stern, 1987), is important for the development of sustainable food production systems, particularly in cropping systems with limited external inputs (Adesogan et al., 2002). This may be due to some of the potential benefits for intercropping systems such a high productivity and profitability (Yildirim and Guvence, 2005), improvement of soil fertility through the addition of nitrogen by fixation and excretion from the component legume (Hauggaard-Nielsen et al., 2001), efficient use of resources (Knudsen et al., 2004), reducing damage caused by pests, diseases and weeds (Banik et 
8

al., 2006; Sekamatte et al., 2003), and improvement forage quality through the complementary effects of two or more crops grown simultaneously on the same area of land (Bingol et al., 2007; Lithourgidis et al., 2007; Ross et al., 2004).

In recent years, advances in plant and animal breeding, introduction of new products and development of new management approaches have made it possible to increase animal performance. However, for this to be realized there must be additional focus on forage quality. In this paper, the production and utilization of cereal-legume intercrops is reviewed, concentrating specifically on the forage quality.

\section{Forage quality definition}

Forage quality is defined as the sum total of the plant constituents that influence an animal's use of the feed. Factors which determined forage quality include the following (Ghanbari-Bonjar, 2000).

Palatability: represents the extent of animal tendency to eat the forage and may influenced by texture, leafiness, moisture content, pest infestation or compounds that cause a forage to taste sweet, sour or salty.

Intake: indicates forage quality which is eaten by animal.

Digestibility: the extent to which forage is absorbed as it passes through an animal's digestive tract.

Nutritive content: the level of nutrients which digested forage provides.

Anti quality factors: various compounds may be present in forage that can lower animal performance, cause sickness or even result in death, including tannins, nitrates, alkaloids, cyanoglycosides, estrogens and mycotoxins. High quality forages must not contain harmful level of anti-quality components.

Animal performance: it can be influenced by any of several factors associated with either the plants or the animals. Failure to give proper consideration to any of these factors may reduce animal's performance level.

\section{Major factors that influence forage quality}

An understanding of factors affecting forage quality will help producers anticipate and plan for changes in forage quality. Six major factors affecting forage quality, ranked by their impact on forage quality including:

Maturity (harvest date): maturity is the most important factor affecting forage quality. Plants continually changes in forage quality as they mature. As plants cell wall content increases, indigestible lignin accumulates which results in decreasing forage quality.

Crop species differences in forage quality between grasses and legumes can be very large. The protein content of legumes is typically much higher than that of grasses and legumes fiber tends to digest faster than grass fiber, allowing the ruminant to eat more of the legume.
Harvest and storage: improper harvest techniques can seriously reduce forage quality, primarily through the loss of leaves. Storing a hay crop at an incorrect moisture content, or improper ensiling of a forage crop, can lower its quality.

Environment: when bad weather delays harvesting, the forage crop becomes more mature and hence lower in quality. High temperatures may increase lignin accumulation and decrease quality, but drought stress actually benefits quality by delaying maturity.

Soil fertility: it is necessary to balance soil fertility to avoid mineral imbalances in ruminants. Low soil fertility, as well as very high fertility, has resulted in reduced forage quality.

Variety (cultivar): this can affect forage quality, but not as greatly as the other five factors.

\section{Important forage quality analysis terms}

Plant morphology for both cereals and legumes has three main plant parts, leaf stem and grain. As a structural component of the plant, stems typically contain more fiber for supports. Leaves, on the other hand, provide a means for capture and utilization of energy from sunlight and trend to be lower in fiber content than stems (Wilman and Rezvani-Moghadam, 1998). Thus, stems usually are lower in digestibility than leaves, and stem digestibility declines more rapidly with increased plant maturity than that of leaves (Gebrehiwot et al., 1996). Differences between leaf and stem digestibility are normally greater in forage legumes than cereals (Buxton, 1996). Given the large difference between the digestible fiber content of stems and leaves, the proportion of leaf to stem in given forage plant relates directly to its forage quality (Ghanbari-Bonjar, 2000). Also, the grain mainly comprises digestible components such as starch and protein. Consequently, grain to stover ratio is considered as an indicator for variety selection when high quality forage is required (Coors et al., 1997).

Forage quality is usually estimated by in vitro or chemical means, because of the cost and time required to conduct feeding trials (Buxton, 1996). A typical forage quality analysis includes measurements of the following factors.

Crude protein $(\mathrm{CP})$ : protein is needed by livestock for growth and milk production. Protein is also needed by rumen bacteria, which digest much of the feed for ruminant animals like cattle, sheep and goats. Protein requirements for livestock usually are expressed as CP (Buxton, 1996) which is the sum of true protein and non-protein nitrogen (includes glutamine, glutamic acid, asparagine, aspartic acid, gamma-amino butyric acid and nitrates). CP is calculated by measuring the nitrogen concentration and multiplying by 6.25 (Boisen and Eggum, 1987). Although high protein forages are also often high in energy, CP content is little value in determining energy content. Since protein is one of the most costly supplements for livestock, high protein forages are desirable. 
Neutral detergent fiber (NDF): represent all of the structural or cell wall mineral in the forage. The NDF of forage is inversely related to the amount that an animal is able to consume, thus, forages with low NDF will have higher intakes than those with high NDF because the filling effect of forage is related to its cell wall content and rate of disappearance of cell walls from the rumen by digestion and passage. Therefore, a low percentage of NDF is desirable.

Acid detergent fiber (ADF): is the percentage of highly indigestible plant material present in forage. It contains cellulose, lignin and silica. Low ADF values means higher energy value and digestibility. Since lignin and silica are not digestible by ruminants, low ADF values are desirable. Also, the difference in the amount of NDF and ADF is an estimate of the hemicellulose in feed (Rebole et al., 1996, Caballero and Goicoechea, 1995).

Ash: measures the total mineral content of forage. Ideally, this should not exceed 85 g. $\mathrm{kg}^{-1}(8.5 \%)$. Certain minerals can affect forage quality. "Grass tetany" is a disorder that is associated with $\mathrm{Mg}$ deficiency in the blood of animals (McDonald et al., 1995). In addition, deficiencies of mineral elements may affect the utilization of forage and may impair the ability of micro-organisms to digest fiber and synthesis of protein.

\section{Cereal-legume intercropping}

A combination of a legume with a cereal is the most common type of intercropping that occurs with annual crops, and the majority of successful intercrops grown world wide also consist of cereal-legume intercrops (Francis, 1989). The main criteria used in selecting the species, especially as forage crops, in intercropping are:

The species should have high protein content.

The species should have a facilitative effect with each other and no antagonistic interaction, i.e, they should exhibit contrasting morphological and physiological characteristics and there should be some temporal differences between the growths of them. In ecological terms, the morphological and physiological differences among species results in their ability to occupy different niches. Thus, the hypothesis here is that in agriculture, environmental factors could be more efficiently utilized by mixed stands of crops than pure stands.

The two species in combination with each other should produce maximum yields at the same harvest time.

The two species should have a same sowing date as much as possible.

The combination of cereals and legumes exhibit most of the above criteria. Thus, the inclusion of a legume in the cereal crop has the potential for improving forage yield and quality. Legumes have been shown to produce high concentration of crude protein depending on cultivar, harvest date and local conditions (Berkenkamp and Meeres, 1987). Improvement of protein content has been recognized as of the benefits of intercropping cereals and legumes in forage production (Herbert et al., 1984). Berkenkamp and Meeres (1987) reported that protein content in the faba bean was on average 2.1 times that of wheat, therefore, the addition of faba bean as legume could be improve the quality of wheat forage, because wheat contains lower crude protein concentrations of $8.4-10.5 \%$, and faba bean as whole crop has been shown to produce high concentration of crude protein of 17-18.5\%. Moreover, legumes produce low dry matter and are known to be weak competitors against weeds (Mohler and Liebman, 1987). Therefore, it seems that growing either legumes or cereals in a sole crop is not ideal for forage production. On the other hand, integration of legumes into the cereal-based farming system may be the key to sustaining soil, crop and livestock production (Caballero and Goicoechea, 1995). Thus, a better alternative might be to grow these species as a mixture.

\section{Maize intercrops}

Maize (Zea mays) is the third most important cereal crop of the word which is used as food, feed and forage. Maize fodder can safely be fed at all stages of growth without any danger of oxalic acid, prussic acid as in case of sorghum or fodders (Dahmardeh et al., 2009). A considerable amount of research has focused on maize forage production. Liu et al (2006) concluded that crude protein of plants in intercropping system was increased by $30.8 \%$ and $99.4 \%$ as compared with those for monocropping maize. Also, Herbert et al (1984) reported that all intercrops produced $8-17 \%$ more total protein $\mathrm{ha}^{-1}$ than corn monoculture Putnam et al (1986) noted increases of 11$51 \%$ in CP concentrations of maize-soyabean intercrops compared with a maize monocrop. This is in agreement with the research of Fujita et al (1992) who reported that protein concentration was increased from $69-81 \mathrm{~g} . \mathrm{kg}^{-1}$ for maize monocrop to $88-108 \mathrm{~g} . \mathrm{kg}^{-1}$ for various intercropping pattern. The higher total protein yield produced by intercropping was attributed to higher forage production by intercrops and also protein content.

Other important characteristics for forage quality are the concentration of NDF, ADF and Ash. The NDF content is important in ration formulation because it reflects the amount of forage that can be consumed by animals (Bingol et al., 2007; Lithourgidis et al., 2006). As NDF percentage increases, dry matter intake decreases (Van Soets, 1994). Lauriault et al (2004) noted that intercropping with pea decreased NDF in all cereal. Forage-legume intercrops compared with their monocultures. Thus, addition of legumes to forage maize can reduce the NDF and ADF concentrations, indicating potential for increasing forage intake. Dahmardeh et al (2009) reported that maximum ADF (31.85\%) was recorded by sowing maize alone while increasing the proportion of cowpea seeds to $50 \%$ in intercropping with maize, resulted in the lowest ADF (25-89\%). Intercropping of cereal and legume can improve forage quality in terms of ash. In this connection, 
10

Anil et al. (2000) reported that ash content was increased by intercropping of maize and runner bean. Mason and Pritchard (1987) stated that mineral absorption percent increases due to complementary effects between components of maize-soyabean intercropping.

It has been reported that different forage quality was obtained at different harvest date in intercropping. Dahmardeh et al. (2009) concluded that maximum crude protein percentage of forage was obtained in milky stage and minimum crude protein was achieved in doughty stage of maize growth period in maize-cowpea intercropping. Decreasing of CP content with increasing maturity reported by Shepard and Kung (1996), while reduction in NDF and ADF concentration of forage from doughty stage compared with milky stage was recorded which can attributed in increasing of grain to whole biomass ratio. In the other word, harvest time affected significantly NDF and ADF concentration. A decline in fiber concentration with increasing maturity can be attributed to the dilution effect created by increasing content of grain as corn matures (Coors et al., 1997).

Maize composition with different legumes may results in different forage quality. For example, Javanmard et al (2009) used two maize hybrids (704 and 301) and four legumes (vetch, bitter vetch, berseem clover and common bean) intercrops to evaluate the effects of legumes on forage yield and quality. They found that $\mathrm{CP}$ yield, dry matter and ash content of maize forage increased by intercropping as compared with maize sole crop. Also, intercropping of legumes with maize significantly reduced NDF and ADF content, thus, increasing digestibility of the forage. Furthermore, forage quality achieved by intercropping was higher in the composition of maize with vetch, bitter vetch and common bean, where NDF and ADF content were higher in maize-berseem clover intercropping.

Seed proportion of intercropping components is also a factor affecting yield and CP content of forage. For instance, Ibraham et al (2006) compared the yield and quality of maize fodder and cowpea sown alone and in mixture with each other in different proportions. They found that the production of crude protein was affected by seed combinations of maize and cow pea in different ratios, where, an increased proportion of cowpea in seed mixture increased the crude protein contents. The cowpea sown alone produced more crude protein $(18.10 \%)$, but the lowest dry matter $\left(4.16\right.$ t.ha $\left.{ }^{-1}\right)$ and maize sown alone produced minimum crude protein $(8.5 \%)$. The seed combination of 75:25 maize and cowpea produced more dry matter $\left(13.26\right.$ t.ha $\left.^{-1}\right)$ and crude protein $(10.45 \%)$ than maize sole crop, suggesting that higher green forage yield and good quality could be attained by mixture of maize and cowpea of 75:25 seed ratio. Dawo et al (2007) concluded that $\mathrm{CP}$ concentration increased $22 \%$ in the mixture when corn proportion decreased by $50 \%$ in the mixture of corn and bean.

\section{Wheat intercrops}

Legumes supply nitrogen to grass-legume mixtures, so it may produce more forage yield than grasses grown alone. Grasses grown in intercropping with legumes also contain a higher percentage of protein. The benefits of forage wheat and legumes are not limited to forage yield and quality. Legumes-wheat combinations should be present in an intercrop canopy which ensures good early interception of light and achieves a higher dry matter yield than sole crops, especially in poor growing conditions. Hamyes and Lee (1994) showed that wheat-legume intercrops could give yield advantages. Additionally in intercrops with wheat, legume grew well and contributed to more use of environmental resources, thus, intercrops were also effective as suppressing weeds. Furthermore, management strategies such as harvest time and fertilizer application can affect dry matter yield and chemical composition and nutritive values of forage. Thus, these factors need to be considered when making management decisions.

Little research has been undertaken on the intercropping wheat for forage. However, wheat may have considerable potential as a intercropped component for forage production. Ghanbari-Bonjar and Lee (2003) evaluated sole crops and intercrops of wheat and field bean for whole crop forage quality characteristics of $\mathrm{CP}, \mathrm{NDF}, \mathrm{ADF}$ and Ash content. They concluded that field been intercropped with wheat led to increased forage quality compared with sole crop wheat, suggesting that wheat-bean intercrops is a relatively high quality low-input and environmentally benign forage crop considerable potential with regard to yield and quality. Contreras-Gova et al (2006) reported that forage quality in terms of NDF and ADF concentration was improved by wheat-clover intercropping compared with wheat sole crop.

Sleugh et al (2000) mentioned that NDF concentration decreased about 30\% in kura clover-wheat grass intercropping. Intercropping experiment combining winter wheat with white clover was conducted by Baldson et al (1997) showed that intercropping may not always results in better forage quality. However, quality analysis of the whole crop herbage showed little difference between the bi-cropping system and conventional system.

\section{Barley intercrops}

Although barley is usually taken through to grain harvest, it is commonly mixed with other forage crop to form grassland establishment (Anil et al., 1998). However, in some systems barley intercropped for forage production. Bingol et al (2007) found that all of the mixtures of vetch and barley had significantly higher digestible dry matter and crude protein yield. Intercropping barley with common vetch improved forage quality and increased protein yield of barley without reducing dry matter yield (Thompson et al., 1992). Ross et al (2004) compared forage quality of four barley and five oat cultivars intercropped with berseem clover and found that forage quality may differ 
among oat and barley cultivars where forage quality indicators suggested that intercrops with barley were superior to those with oat. Stout et al (1997) found that composition of legumes such as berseem clover, annual Lucerne and Persian clover were potentially of use for intercropping with barley-ryegrass, generally having higher forage quality, although yields were lower than the fertilize red barley-ryegrass intercrops.

Stryhorst et al (2008) found that although different legume-barley composition may led to different forage quality, all barley intercrops with legumes resulted in higher forage quality than barley monoculture, where, faba beanbarley, lupin-barley and pea-barley intercrops had 64, 27 and $55 \%$ higher protein yield compared to the barley sole crop, respectively.

Dry matter yield is an important factor in determining crude protein yield of barley. In this connection, Yolcu et al (2009) evaluated forage yield and quality of barley intercropped with annual legumes in two years and found that crude protein yield in the $1^{\text {st }}$ year was higher than those of $2^{\text {nd }}$ year, which resulted by harmful effect of frost to dry matter production in the $2^{\text {nd }}$ year. In the other word, lower dry matter production in the $2^{\text {nd }}$ year, led to lower crude protein yield. In addition, forage quality in terms of NDF and ADF was improved by intercrop compared with barley sole crop, but barley forage quality was better than barley-common vetch intercropping in terms of crude protein content and yield, because NDF, ADF and CP of sole barley were $57.5 \%, 36.4 \%$ and $13 \%$ respectively and those of intercrops were $46 \%, 30.3 \%$ and $12 \%$ respectively.

\section{Other intercrop compositions}

Legumes are also important in animal feeding. For example, soyabean is desirable as a forage crop because of higher protein concentration than is found in many other forages. This annual legume, which is usually grown in mixtures with small grain cereals for hay or forage production, was first introduced into the USA for use as a high yielding forage crop. Today, most soybean cultivars presently used for forage are shorter than grain types (Hintz et al., 1992). Redfearn et al (1992), working on forage production of soyabean intercropped with sorghum, mentioned that leaf and stem components differed in their contribution to overall dry matter yield of monocrop and intercropped soyabean, where leaf and stem yield were approximately $56 \%$ greater in monocrop soybean than intercropped soyabean. The authors reported that shading of soyabean by sorghum in intercropping resulted in decreased dry matter accumulation. Regarding to forage quality, fiber concentration and fiber composition of leaves were not different between monocrop and intercropped soyabean. Monocrop soyabean stems had $36 \mathrm{~g} \mathrm{~kg}^{-1}$ greater NDF and $24 \mathrm{~g} \mathrm{~kg}^{-1}$ greater ADF concentration than intercropped soyabeen stem. Averaged across upper and lower canopies, leaves of monocrop soyabean had $25 \mathrm{~g} \mathrm{~kg}^{-1}$ greater $\mathrm{CP}$ than leaves of intercropped soyabean. Conversely, CP concen- tration for intercropped soyabean stems was $12 \mathrm{~g} \mathrm{~kg}^{-1}$ greater than monocrop soyabean stem. These differences in forage quality may be mostly related with developmental characteristics. However, changes in plant metabolism could have occurred, because of altered irradiance within the intercropped plots.

The quality of forage produced by monocropped oat and triticale was improved by intercropping. Ross et al (2004) concluded that the addition of berseem clover to oat, reduced the neutral detergent fiber (NDF) concentration by an average of $30 \mathrm{~g} \mathrm{~kg}^{-1} \mathrm{DM}$, indicating potential for increasing forage intake. Droushiotis (1998) reported that intercropping improved forage quality in terms of crude protein and ash content in the oat-vetch and triticale-pea intercropping. However, suitable intercropping of oat and triticale for forage production has been discussed. Caballero and Goicoechea (1986) and Thomson et al (1990) reported that the most suitable cereal for mixtures with common vetch is oat while Anil et al (1998) mentioned that triticale can be used as an alternative cereal for mixtures with common vetch. Lithourgidis et al (2006) evaluated common vetch, triticale and oat monocultures as well as mixtures of common vetch with each other of the above cereals in two seeding ratios (55:45 and 65:35) for forage yield and quality. They found that in all mixtures, the $\mathrm{CP}$ content increased as common vetch seeding proportion increased. Monoculture common vetch had the highest CP content (139.3 $\mathrm{g} \mathrm{kg}^{-1}$ of DM), followed by the mixture of common vetch with oat $(65: 35)\left(119.1 \mathrm{~g} \mathrm{~kg}^{-1}\right.$ of $\mathrm{DM})$ and the two mixtures of common vetch with triticale (109.2 and $103 \mathrm{~g} \mathrm{~kg}^{-1}$ of DM, respectively). In contrast, triticale and oat monocultures had the lowest CP (63.2 and $78.4 \mathrm{~g} \mathrm{~kg}^{-1}$ of $\mathrm{D}$, respectively). Although the mixture of common vetch-oat (65:35) had the lowest $\mathrm{CP}$ content than monoculture common vetch, it gave the highest CP per ha than all crops, because of its higher forage yield. The CP per ha was the lowest for monoculture triticale $(680 \mathrm{~kg}$ $\left.\mathrm{ha}^{-1}\right)$ and the mixture of common vetch-triticale (55:45) $\left(790 \mathrm{~kg} \mathrm{ha}^{-1}\right)$. In addition, higher CP per ha was found in oat than in triticale because of the higher amount of protein and large biomass that oat produced compared with triticale.

\section{Conclusions}

Overall, results of researches reviewed in this paper, showed that cereal-legume intercropping can be used as a suitable management strategy for producing high quality and quantity forage. Because intercropping improves forage quality compared with cereals monoculture, and produces more dry matter compared with legumes sole crop. In the other word, forage with acceptable degree of quality and quantity can be attained by cereal-legume intercropping.

Crude protein yield can be affected by dry matter production. It means that a cereals-legume intercropping com- 
12

position may have more crude protein content but lower crude protein yield per unit area than the other. Although forage produced by common vetch sole crop had more crude protein than oat-common vetch intercropping, the crude protein yield $\left(\mathrm{kg} \mathrm{ha}^{-1}\right)$ was more in the oat-common vetch intercropping, suggesting that dry matter production is an important factor in determining crude protein yield per unit area.

Composition of different legumes with a specific cereal resulted in forages with different quality, where forage quality of corn-bitter vetch intercropping was better than the mixture of corn with common been or berseem clover. It can be also occurred with the intercropping of different cereals with a specific legume. Oat is a better cereal than triticale for intercropping with common vetch, because oat has more crude protein and also produces more dry matter compared with triticale. On the other hand, forage quality of barley-common vetch intercropping was higher than oat-common vetch intercropping. Thus, suitable cereals as component of cereals-common vetch intercropping are barley, oat and triticale, respectively.

Finally, crop species, cultivar, harvest date and seed proportion are important factors which must be regarded for selecting suitable cereal-legume intercropping components.

\section{References}

Adesogan, A. T., M. B. Salawu and E. Deaville (2000). The effect on voluntary feed intake, in vivo digestibility and nitrogen balance in sheep of feeding grass silage or pea-wheat intercrops differing in pea to wheat ratio and maturity. Animal Feed Science and Technology. 96:161-173.

Anil, L., J. Park and R. H. Phipps (2000). The potential of forage-maize intercrops in ruminant nutrition. Animal Feed Science and Technology. 85:157-164.

Anil, L., J. Park, R. H. Phipps and F. Miller (1998). Temperate intercropping of cereal for forage: a review of potential for growth and utilization with particular reference to the UK. Grass and Forage Science. 53:301-317.

Baldson, S. L., T. M. Martin, R. O. Clements and S. George (1997). The potential of a clover-cereal bi-cropping system to produce high quality whole-crop silage. Fifth Research Conference British Grassland Society, 8-10 September 1997. Seale Hayne Faculty of Agriculture, Food and Land Use, University of Plymouth, UK. p. 85-86.

Bingol, N. T., M. A. Karsli, I. H. Yilmaz and D. Bolat (2007). The effects of planting time and combination on the nutrient composition and digestible dry matter yield of four mixtures of vetch varieties intercropped with barley. Journal of Veterinary Animal Science. 31:297-302.

Boisen, S. E. and B. O. Eggum (1987). A critical view on the conversion factor 6.25 from total nitrogen to protein. Acta Agronomica, 37:299-304.

Buxton, D. R. (1996). Quality-related characteristics of forage as influenced by plant environment and agronomic factors. Animal Feed Science and Technology. 53:37-49.

Caballero, R. and E. L. Goicoechea (1995). Forage yield quality of common vetch and oat sown varying seeding ratios and seeding rates of vetch. Field Crops Research. 41:135-140.

Caballero, R. and E. L. Goicoechea (1998). Utilization of winter cereals as companion crops for common vetch and hairy vetch. Proceedings of the $11^{\text {th }}$ General Meeting of the European Grass Fed. pp. 273-284.

Contreras-Gova, F. E., K. A. Albrecht and R. E. Muck (2006). Spring yield and silage characteristics of Kura clover, winter wheat and mixtures. Agronomy Journal. 98:781-787.

Coors, J. G., K. A. Albrecht and E. J. Bures (1997). Ear-fill effects on yield and quality of silage corn. Crop Science. 37:243-247.

Dahmardeh, M., A. Ghanbari, B. Syasar and M. Ramroudi (2009). Effect of intercropping maize with cowpea on green forage yield and quality evaluation. Asian Journal of Plant Sciences. 8 (3):235-239.

Dawo, M. I., M. Wilkinson, F. E. Sanders and D. J. Pilbeam (2007). The yield and quality of fresh and ensiled plant material from intercropping maize and bean. Journal of Science of Food and Agriculture. 87:1391-1399.

Droushiotis, N. D. (1998). Mixtures of annual legumes and small grained cereals for forage production under low rainfall. Journal of Agricultural Science. 43:249-253.

Francis, C. A. (1989). Biological efficiencies in multiple cropping systems. Advance in Agronomy. 42:1-42.

Fujita, K., K. G. Ofosu-Buda and S. Ogata (1992). Biological nitrogen fixation in mixed legume-cereal cropping system. Plant and Soil. 141:155-175.

Gebrehiwot, L., R. L. McGrow and G. Assefu (1996). Forage yield and quality profile of three annual legumes in the tropical highlands of Ethiopia. Journal of Agriculture. 73:83-98.

Ghanbari-Bonjar, A. (2000). Intercropped wheat (Triticum aestivum) and bean (Vicia faba) as a low-input forage. $\mathrm{PhD}$ thesis, Wye College, University of London.

Ghanbari-Bonjar, A. and H. C. Lee (2003). Intercropped wheat and bean as whole crop forage: effect of harvest time on forage yield and quality. Grass and Forage Science. 58(1):28 36.

Hauggaard-Nielsen, H., P. Ambus and E. S. Jensen (2001). Interspecific competition, $\mathrm{N}$ use and interference with weeds in pea-barley intercropping. Field Crops Research. 70:101-109.

Haymes, R. and H. C. Lee (1994). Agronomic aspects of wheatbean intercropping in a low input system. Proceedings of $3 \mathrm{rd}$ ESA Congress on Sustainable Agriculture. Abavo-Pavoda. Pp. 706-707.

Herbert, S. J., D. H. Putnam and J. F. Creighton (1984). Forage yield intercropped corn and soyabean in various planting patterns. Agronomy Journal. 76:507-510. 
Hintz, R.W., K. A. Albretch and E. S. Oplinger (1992). Yield and chemical composition of soybean forage as affected by cultivar and management practices. Agronomy Journal. 84:795-798.

Ibrahim, M., M. Rafiq and A. Sultan (2006). Green fodder yield and quality evaluation of maize and cow pea sown alone and in combination. Journal of Agricultural Research. 44(1):1521.

Javanmard, A., A. Dabbagh-Mohammadi, A. Nasab, A.Javanshir, M. Moghadam and H. Janmohammadi (2009). Forage yield and quality in intercropping of maize with different legumes as double cropped. Journal of Food, Agriculture and Environment. 7(1):163-166.

Lauriault, L. M. and R. E. Kirksey (2004). Yield and nutritive value of irrigated cereal forage grass-legume intercrops in the southern high plains, USA. Agronomy Journal. 96:352358.

Leaver, J. D. and J. Hill (1992). Feeding cattle on whole-crop cereal. In Stark B.A and J.M. Wilkinson (eds) whole-crop cereals. Second edition. Chalcobe Publication. pp:59-72.

Lithourgidis, A. S., I. B. Vasilakoglou, K. V. Dhima, C. A. Dordas and M. D. Yiakoulaki (2006). Forage yield and quality of common vetch mixtures with oat and triticale in two seeding ratio. Field Crops Research. 99:106-113.

Liu, J. H., Z. H. Zeng, L. X. Jiao, Y. G. Hu, Y. Wang and H. Li (2006). Intercropping of different silage maize cultivars and alfalfa. Acta Agronomica. 32:125-130.

Mason, W. and K. T. Pritchard (1986). Intercropping in a temperate environment for irrigated fodder production. Field Crops Research. 16:243-253.

McDonald, P. E., R. D. Edwards and C. A. Morgan (1995). Animal nutrition. Fifth edition. Wiley, J and sons. USA. pp. 122-128.

Mohler, C. L. and M. Liebman (1987). Weed productivity and composition in sole crops and intercrops of barley and field bean. Journal of Applied Ecology. 24:685-699.

Ofori, F. and W. R. Stern (1987). Cereal-legume intercropping system. Advance in Agronomy. 41:41-90.

Putnam, D. M., S. J. Herbert and A. Vargas (1986). Intercropped corn-soyabean density studies. $\Pi$. Yield composition and protein. Experimental Agriculture, 22:373-381.

Rebole, A., J. Trevino and R. Caballero (1996). Chemical change associated with the field drying of oat forage. Field Crops Research. 47:221-226.

Redfeara, D. D., D. R. Buxton and T. E. Devine (1999). Sorghum intercropping effect on yield, morphology and quality of forage soybean. Crop Science. 39:1380-1384.
Ross, S. M., J. R. King, J. T. O’Donovan and D. Spaner (2004). Intercropping berseem clover with barley and oat cultivars for forage. Agronomy Journal. 96:1719-1729.

Ross, S. M., J. R. King, J. T. Donovan and D. Spaner (2005). The productivity of oats and berseem clover intercrops. I. Priming growth characteristics and forage quality at four densities of oats. Grass and Forage Science. 60:74-86.

Sheperd, A. C. and J. K. Kung (1996). Effect of an enzyme addition on composition of corn silage ensiled at various stages of maturity. Dairy Science. 79:1767-1773.

Sleugh, B., K. J. Moore, J. Ronald-George and C. Brummer (2000). Binary legume-grass mixtures improve forage yield, quality and seasonal distribution. Agronomy Journal. 92:2429.

Stout, D. G., B. Brooke, J. W. Hall and D. J. Thompson (1997). Forage yield and quality from intercropped barley, annual ryegrass and different legumes. Grass and forage Science. 52:298-308.

Strydhorst, S. M., J. R. King, K. J. Lopetinsky and K. Neil-harker (2008). Forage potential of intercropping barley with faba bean, lupine or field bean. Agronomy Journal. 100:182190.

Thompson, D. J., D. G. Stout and T. Moore (1992). Forage production by 4 annual cropping sequences emphasizing barley under irrigation in southern interior British Columbia. Canadian Journal of Plant Science. 72:181-185.

Thompson, E. F., S. Rihawi and N. Nersoyan (1990). Nutritive value and yields of some forage legumes and barley harvested as immature herbage, hay and straw in North-West Syria. Experimental Agriculture. 26:49-56.

Van Soet, P. J. (1994). Nutritional ecology of the ruminants. In Van Soet P. J. Fiber and physiochemical properties of feeds. $2^{\text {th }}$ edn. Cornell University Press, Ithaca and London. pp. 140-155.

Wilman, D. and P. Rezvani-Moghaddam (1998). In vitro digestibility and neutral detergent fiber and lignin content of plant parts of nine forage species. Journal of Agricultural Science. 131:51-58.

Yildirim, E. and I. Guvence (2005). Intercropping based on cauliflower: more productivity, profitable and highly sustainable. European Journal of Agronomy. 22:11-18.

Yolcu, H., M. Dasci and M. Tan (2009). Evaluation of annual legumes and barley as sole crops and intercrop in spring frost conditions for animal feeding. I. Yield and quality. Journal of Animal and Veterinary Advances. 8(7):1337-1342. 